Article

\title{
Smart-Hydroponic-Based Framework for Saffron Cultivation: A Precision Smart Agriculture Perspective
}

\author{
Kanwalpreet Kour ${ }^{1}$, Deepali Gupta ${ }^{1}{ }^{\oplus}$, Kamali Gupta ${ }^{1}$, Gaurav Dhiman ${ }^{2}{ }^{\circledR}$, Sapna Juneja ${ }^{3}$, \\ Wattana Viriyasitavat ${ }^{4}$, Hamidreza Mohafez ${ }^{5, *(1)}$ and Mohammad Aminul Islam ${ }^{6}(\mathbb{C}$
}

1 Chitkara University Institute of Engineering \& Technology, Chitkara University, Rajpura 140401, India; kanwalpreet.kour@chitkara.edu.in (K.K.); deepali.gupta@chitkara.edu.in (D.G.); kamali.singla@chitkara.edu.in (K.G.)

2 Department of Computer Science, Government Bikram College of Commerce, Patiala 147001, India; gdhiman0001@gmail.com

3 KIET Group of Institutions, Delhi NCR Campus, Ghaziabad 201206, India; sapna.juneja@kiet.edu

4 Department of Statistics, Chulalongkorn University, Bangkok 10330, Thailand; hardgolf@gmail.com

5 Department of Biomedical Engineering, Faculty of Engineering, Universiti Malaya, Kuala Lumpur 50603, Malaysia

6 Department of Electrical Engineering, Faculty of Engineering, Universiti Malaya, Kuala Lumpur 50603, Malaysia; aminul.islam@um.edu.my

* Correspondence: h.mohafez@um.edu.my

check for updates

Citation: Kour, K.; Gupta, D.; Gupta,

K.; Dhiman, G.; Juneja, S.;

Viriyasitavat, W.; Mohafez, H.; Islam, M.A. Smart-Hydroponic-Based Framework for Saffron Cultivation: A Precision Smart Agriculture Perspective. Sustainability 2022, 14, 1120. https://doi.org/10.3390/ su14031120

Academic Editor: Anastasios Michailidis

Received: 20 November 2021 Accepted: 11 January 2022

Published: 19 January 2022

Publisher's Note: MDPI stays neutral with regard to jurisdictional claims in published maps and institutional affiliations.

Copyright: (C) 2022 by the authors. Licensee MDPI, Basel, Switzerland. This article is an open access article distributed under the terms and conditions of the Creative Commons Attribution (CC BY) license (https:// creativecommons.org/licenses/by/ $4.0 /)$.

\begin{abstract}
Saffron, one of the most expensive crops on earth, having a vast domain of applications, has the potential to boost the economy of India. The cultivation of saffron has been immensely affected in the past few years due to the changing climate. Despite the use of different artificial methods for cultivation, hydroponic approaches using the IoT prove to give the best results. The presented study consists of potential artificial approaches used for cultivation and the selection of hydroponics as the best approach out of these based on different parameters. This paper also provides a comparative analysis of six present hydroponic approaches. The research work on different factors of saffron, such as the parameters responsible for growth, reasons for the decline in growth, and different agronomical variables, has been shown graphically. A smart hydroponic system for saffron cultivation has been proposed using the NFT (nutrient film technique) and renewable sources of energy.
\end{abstract}

Keywords: IoT; saffron; NFT; hydroponics; WSN

\section{Introduction}

Agriculture is considered to be the backbone of the Indian economy, contributing to about 18 percent of the Gross Domestic Product (GDP) and 43 percent of the geographical area [1]. With the drastically increasing population, the world population is supposed to reach 9.8 billion by the year 2050, with its maximum impact being on developing nations such as India [2,3]. Agriculture, being the primary source of food, requires a great deal of evolution and technology [2,4]. Hence there is a great need for maximizing the economic potential of agriculture. This can be achieved by improving the cultivation of economically potent crops like saffron.

Saffron is the most expensive crop throughout the world and can be helped to boost the economy of a country to a great extent. Available data shows that the economies of nations such as Afghanistan and Italy have been immensely benefited by saffron cultivation $[5,6]$. The largest and the best quality saffron-producing area, Herat, has generated more than USD 2.6 billion by increasing the land under saffron cultivation by 21 percent to 6200 hectares [6,7]. The world production of Saffron is estimated to be more than 200 metric tons annually $[5,8]$. The chief producers of the crop are Iran, Afghanistan, India, Spain, Italy, and Greece [5,9]. However, some countries are experiencing a sudden decline in the production of the crop such as Spain, Italy, Greece, and India [8]. This makes Iran one 
of the lead producers of the crop, estimated to provide 90 percent of the world's saffron production [8]. The yield and quality of the crop can be increased by monitoring the environmental conditions, which can be easily achieved by using Internet of Things (IoT) sensors [10].

The IoT may be defined as a vast network which allows any things and people to be connected anytime, anywhere, using a service $[11,12]$. In the last few years, the number of devices encompassing the Internet of Things (IoT) has increased from 0.9 billion things in the year 2008 to 50 billion by the end of the year 2020, making it a part of every application in existence [11,13-15]. The IoT is also used in various smart agriculture solutions. One of the most common methods used for the artificial cultivation of crops is hydroponics [16]. It may be defined as a hydroculture technique that does not rely on soil for cultivation [17]. In this method, nutrient solutions rich in micro and macronutrients are provided to the plant through water [16,17]. Different kinds of hydroponic techniques are present such as the nutrient film technique (NFT), thin-film, drip irrigation, the ebb and flow system, and the continual-flow system, which will be discussed in detail in the later sections $[16,18]$. There has been a trending decline in the cultivation of saffron due to numerous factors. The production of saffron has decreased to 5.91 tons in 2019, from 9.85 MT in 2011 [19-24]. Saffron is a highly laborious crop, requiring lots of meticulous work and manual operations. The drying of the stigmas also has to be conducted at low temperatures (below $55^{\circ} \mathrm{C}$ ) to maintain all the benefits [25-27]. Not keeping the basal part of the stigmas intact is what leads to quality compromise. Due to the lack of proper storage houses adjacent to the farms, the crop is not stored as per scientific norms in cool, dark, and dry places, hence leading to adulteration [27-29].

As per the reports from the Agriculture and Revenue Department of Jammu and Kashmir (J and K), India, there is no greater increase in the production of saffron [19]. Comparing the data from the past 10 years, the production can be plotted graphically as shown in Figure 1 [19,22-24].

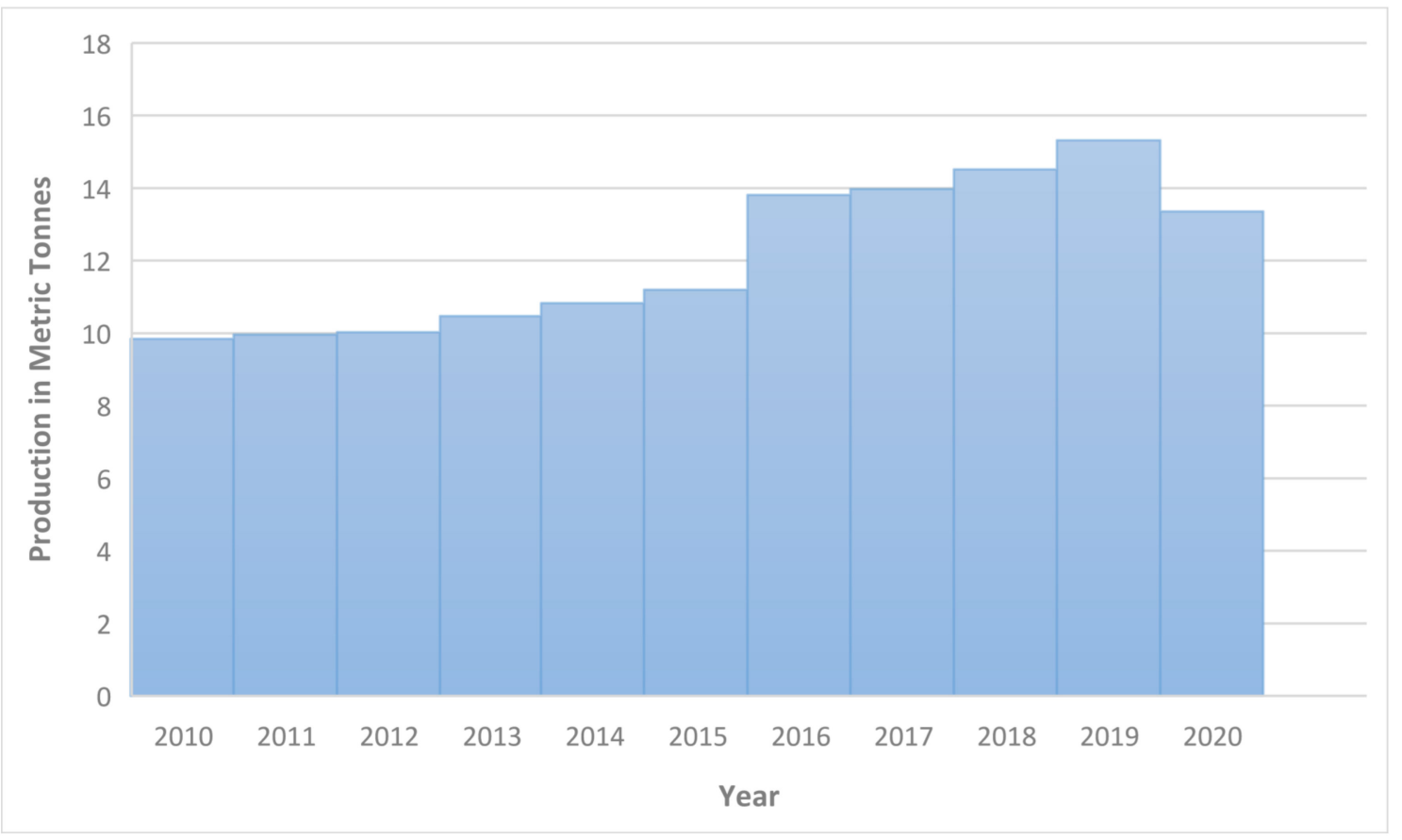

Figure 1. Saffron Production over the years in J and K, India.

The world-wide production of saffron is 200 MT, out of which Iran used to contribute approximately 178 tons [8]. The greater the export, the more the economy of the nation can be benefited. It can be clearly seen in Figure 2 that there is a great need to increase the production and export of saffron so that it can provide greater economic benefits. As shown 
in Figure 2, the leading producers, and exporters of saffron are Iran, Spain, Afghanistan, Greece, Italy, and India [19,22-24]. The major contributions of this paper are as follows:

- Providing a detailed summary of saffron cultivation and reasons for the decline in yield.

- Comparative analysis of different hydroponic approaches.

- Different artificial approaches used for the cultivation of saffron.

- Smart Hydroponic system for saffron cultivation.

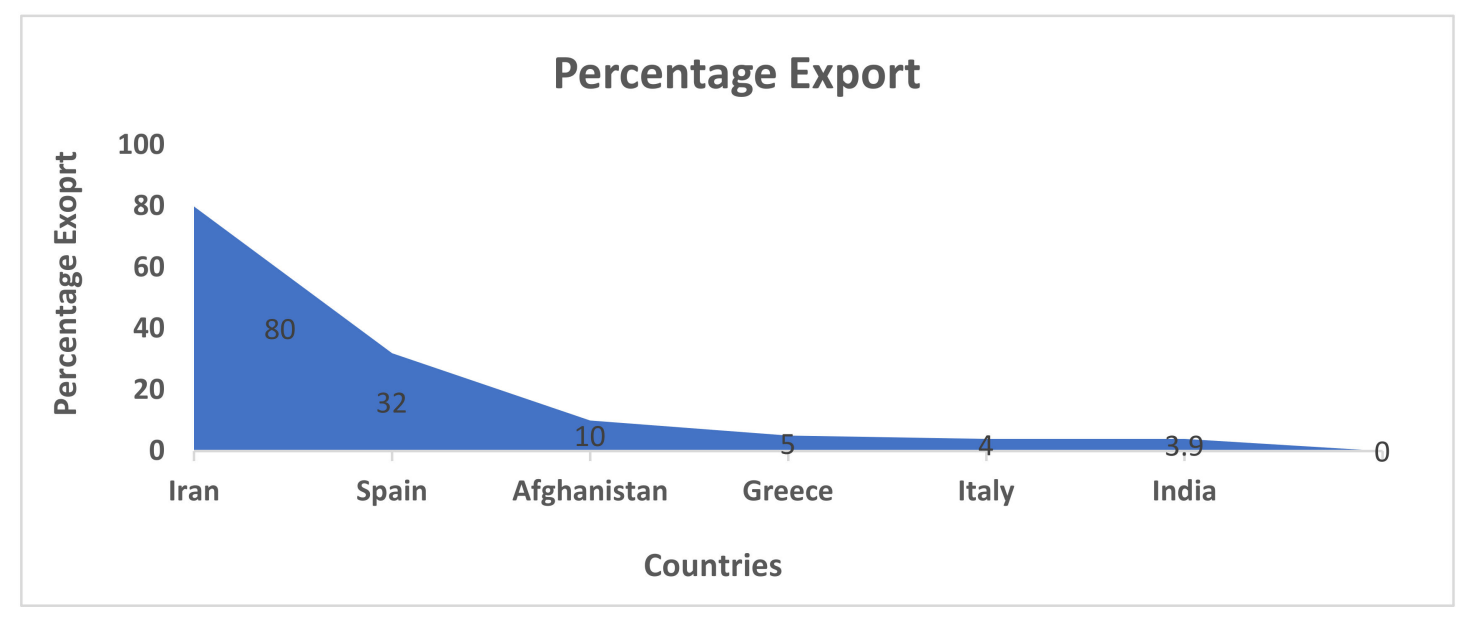

Figure 2. Percentage export of saffron by different countries.

The structuring of contributions in this paper is presented as follows: Section 2 presents various approaches used for saffron cultivation using the IoT and provides a summary of the findings. Section 3 illustrates the research methodology used to select papers from various databases and the process adopted to select the best quality papers. Section 4 outlines important aspects that address various considerations for saffron cultivation using the IoT. Section 5 proposes a smart hydroponic system approach used for saffron cultivation. Section 6 discusses the future scope of the developed hydroponic system with a conclusion.

\section{Literature Review}

Most of the issues arising in traditional farming methods such as more time consumption, deficiency of nutrients in soil, more space consumption, and the huge manpower requirement, can be easily addressed using artificial methods of cultivation [30]. The IoT, along with other technologies such as Big Data, Machine Learning, and Robotics, can be used in the development of various smart farming techniques which can be helpful in addressing all the issues of traditional crop cultivation [31,32]. Hydroculture is the technique of cultivating plants without using soil as a medium [33]. It is classified into several subtypes, as given in Figure 3 [33-35]. Hydroculture involves growing plants in any medium other than soil, such as clay pebbles, rockwool, or aquatic medium [34]. Various other types of hydroculture techniques, such as aeroponics, involve the use of air as a medium of growth for plants by suspending them in mid-air, while aquaponics involves the use of a complete ecosystem so that the output from aquatic animals can contribute to plant growth. The issue in the use of both of these systems is the cost, space consumption, suitability for selective crops, and one-point failure leading to a complete malfunction of the system $[36,37]$. 


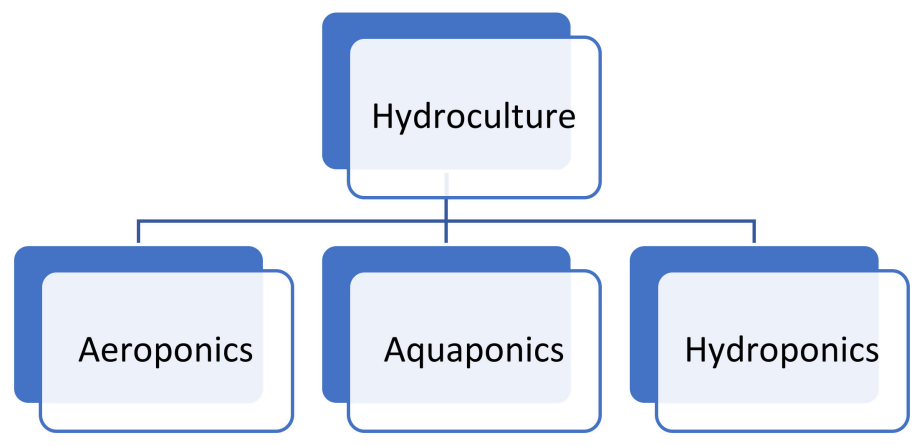

Figure 3. Different Hydroculture Systems.

\subsection{Aeroponics}

Aeroponics refers to the artificial soilless method of plant cultivation in which plant roots are kept hanging in the air and the nutrients are provided to the plant using sprays through nozzles, either continuously or after fixed intervals [38]. This technique has been widely used in the research of plant physiology and growing plants by NASA; however, it is not as commonly used as hydroponics [38,39]. This method is mostly suited for small vegetable crops, such as cucumber, tomatoes, lettuce, herbs, and medicinal plants, where the roots serve as the end product [39]. The method requires a specially designed room for installation and the maintenance cost is huge $[40,41]$.

Kerns et al., proposed an automated indoor cultivation system using aeroponics using Arduino and different sensors. This system is well-suited for indoor farming in urban areas. Webservices and continuous data monitoring are the important factors controlling this system. The system is user-friendly, without many complex operating procedures [42].

Francis et al., proposed an IoT-based aeroponic system that is pest- and disease-free for healthier plant growth. Various sensors for measuring and controlling temperature, $\mathrm{pH}$, and humidity have been used. The system is placed in an indoor location and the light for photosynthesis is obtained by using LEDs. The nutrient-rich mist is sprayed using a spray jet. Sensor data is continuously collected after regular intervals and monitored. Data from each sensor is collected and analyzed individually [43].

Salazar et al., also proposed an IoT-based aeroponic system with automated irrigation. This system is designed for the arugula plant. Different irrigation cycles are generated by using software-based electronic circuits which work by generating irrigation cycles after fixed intervals in Simulink (MATLAB). Using this approach, the time taken to obtain the yield was considerably reduced to five weeks [44].

Jamhari et al., designed an indoor IoT system for six vegetable plants in an aeroponic environment. The reason for using an aeroponic system was reduced water usage. The system was automatically monitored using the IoT. ADHT11 temperature sensor was connected to a microprocessor and a Wi-Fi module and used for monitoring and maintaining a temperature of $25-30^{\circ} \mathrm{C}$, which is ideal for vegetable growth. Humidity and light intensity were also continuously monitored in the system [45].

Mangaiyarkarasi et al., also reviewed the use of an aeroponic system for the cultivation of horticulture crops such as saffron. The essential nutrients are supplied to the air-suspended roots using spray filming techniques. Light penetration and algae growth is avoided by using a sealed box to promote faster root growth. The nutrient spray duration is also calculated for crops such as tomatoes, cucumber, saffron, lettuce, peas, and onions, etc. [46].

Fallahi et al., also cultivated saffron in a soilless medium using aeroponics. The corms used for plantation were obtained from non-flowering small mother corms in a controlled environment. The impact of the use of corms from a controlled environment was used to study the effect on the yield. The water-holding capacity and nutrient absorption of the roots were increased by using superabsorbent. The new corms obtained after growth had 
increased weight and mass. Some of the limitations of this method were the production of contractile roots and the drying of aerial parts [47].

Razavizadeh et al., have studied the quality parameters, i.e. crocin, safranal, and picrocrocin, of saffron grown in an aeroponic environment using plant acoustic frequency technology (PAFT) and liquid chromatography and treated corms for growing with highfrequency sound waves. The aeroponic growth chamber monitored and controlled all the factors such as relative humidity, temperature, and light. The results from the experiment concluded that some metabolites show a positive effect on the quality of the saffron [48].

Ebrahimi et al., studied parameters such as the weight, apocarotenoid, safranal, and picrocrocin content of the corms used for sowing on the yield and quality of saffron produced from it in an aeroponic environment. The mother corms were divided into three categories with weights in increasing order. It was observed that there was an increase in the safranal, picrocrocin, apocarotenoid, and the number of flowers per plant with the increase in the weight of the mother corms up to $16 \mathrm{~g}$ [49].

Salas et al., aimed to study the aeroponic cultivation of saffron and the features of the nutrient solution used. The cultivation of the plant was carried out at Almeria University using $15 \mathrm{~L}$ pots, and the soil replacement medium used was perlite. The parameters studied included the shoot length, corm yield, and nutrient solution concentration in the plants. It was observed that a nutrient intake increase resulted in an increase in production [50].

Eldridge et al., studied the cultivation of saffron in both aeroponic and hydroponic environments and identified the future research areas and research gaps in the aeroponic environment. It was found out in the study that no-matter aeroponics serves as an important vertical farming method, leading to productivity gains and less space consumption, but this generalization is limited to certain crops, mostly vegetables and smaller herbs. In the case of saffron, aeroponic cultivation leads to an increase in corm production and unaltered yield, but an improvement in the quality of petals and an increase in production of flowering patterns have not been reported. It has been concluded that the use of the aeroponic method for root crop cultivation should be conducted only after analyzing the crop variety and parameters related to root morphology and anatomy, such as photoperiod cycles, recycling of roots, microbial impact on roots etc. [51].

The comparison of the above models as per their performance can be seen in Table 1 .

Table 1. Comparison of existing aeroponic models.

\begin{tabular}{|c|c|c|c|c|}
\hline Ref. & Nature of System & Parameters Used & Advantages & Drawbacks \\
\hline [42] & $\begin{array}{l}\text { Automated aeroponics } \\
\text { system using the IoT for } \\
\text { smart farming. }\end{array}$ & $\begin{array}{l}\text { Temperature, } \\
\text { pH, humidity. }\end{array}$ & $\begin{array}{l}\text { User friendly; no } \\
\text { complex operating } \\
\text { procedures. } \\
\text { Well-suited for } \\
\text { indoor farming. }\end{array}$ & $\begin{array}{l}\text { Not fully automated. } \\
\text { Costly. }\end{array}$ \\
\hline [43] & $\begin{array}{l}\text { IoT-based automated } \\
\text { aeroponics system. }\end{array}$ & $\begin{array}{l}\text { Temperature, } \\
\text { pH, humidity. }\end{array}$ & $\begin{array}{l}\text { Controls temperature } \\
\text { and humidity effectively. }\end{array}$ & $\begin{array}{l}\text { Lack of synchronization } \\
\text { among all the units. } \\
\text { Lacks remote } \\
\text { data monitoring. }\end{array}$ \\
\hline$[44]$ & $\begin{array}{l}\text { Arugula plant cultivation } \\
\text { using aeroponic culture } \\
\text { with an automated } \\
\text { irrigation system. }\end{array}$ & Temperature, light, pH. & $\begin{array}{l}\text { Time taken to obtain the } \\
\text { yield was reduced to } \\
\text { five weeks. }\end{array}$ & $\begin{array}{l}\text { Showed decrease in leaf } \\
\text { and root size. }\end{array}$ \\
\hline$[45]$ & $\begin{array}{l}\text { IoT system for aeroponic } \\
\text { chamber with } \\
\text { temperature monitoring. }\end{array}$ & Humidity, light intensity. & $\begin{array}{c}\text { Reduced water } \\
\text { consumption. } \\
\text { Covers variety of crops. }\end{array}$ & $\begin{array}{l}\text { Parameters such as } \\
\text { temperature } \\
\text { not considered. }\end{array}$ \\
\hline [46] & $\begin{array}{l}\text { Aeroponics system for } \\
\text { production of } \\
\text { horticultural crops. }\end{array}$ & $\begin{array}{l}\text { Light penetration, } \\
\text { algae growth. }\end{array}$ & $\begin{array}{l}\text { Water efficient; involves } \\
\text { low mineral } \\
\text { consumption. }\end{array}$ & $\begin{array}{l}\text { Less space for } \\
\text { root expansion. }\end{array}$ \\
\hline
\end{tabular}


Table 1. Cont.

\begin{tabular}{|c|c|c|c|c|}
\hline Ref. & Nature of System & Parameters Used & Advantages & Drawbacks \\
\hline [47] & $\begin{array}{l}\text { Evaluation the possibility } \\
\text { of saffron transplanting } \\
\text { and corm production } \\
\text { in aeroponics. }\end{array}$ & Corm size. & Increased corm size. & $\begin{array}{l}\text { Production of contractile } \\
\text { roots; drying of } \\
\text { aerial parts. }\end{array}$ \\
\hline [48] & $\begin{array}{l}\text { Quantification of safranal } \\
\text { and other pigments in } \\
\text { saffron stigmas } \\
\text { using PAFT. }\end{array}$ & $\begin{array}{l}\text { Crocin, safranal, } \\
\text { and picrocrocin. }\end{array}$ & $\begin{array}{l}\text { Novel approach to } \\
\text { improve saffron quality. }\end{array}$ & $\begin{array}{l}\text { More research in } \\
\text { determining the duration } \\
\text { of exposure and } \\
\text { other factors. }\end{array}$ \\
\hline [49] & $\begin{array}{l}\text { Effect of corm weight on } \\
\text { the yield, growth, } \\
\text { pigments and production } \\
\text { of corms in saffron } \\
\text { aeroponic cultivation. }\end{array}$ & $\begin{array}{l}\text { Weight, apocarotenoid, } \\
\text { safranal, and picrocrocin. }\end{array}$ & $\begin{array}{l}\text { Resulted in increase in } \\
\text { the weight of mother } \\
\text { corms upto } 16 \mathrm{~g} .\end{array}$ & $\begin{array}{c}\text { No increase in corm size } \\
\text { beyond a limit. }\end{array}$ \\
\hline [50] & $\begin{array}{l}\text { Optimal strength of the } \\
\text { nutrient solution for } \\
\text { aeroponic cultivation } \\
\text { of saffron. }\end{array}$ & $\begin{array}{l}\text { Shoot length, corm yield, } \\
\text { and nutrient } \\
\text { solution concentration. }\end{array}$ & $\begin{array}{l}\text { Impact of nutrient } \\
\text { solution on yield and } \\
\text { quality studied. }\end{array}$ & $\begin{array}{l}\text { Components of nutrient } \\
\text { solution based on } \\
\text { different crops } \\
\text { not analyzed. }\end{array}$ \\
\hline [51] & $\begin{array}{l}\text { Getting to the roots of } \\
\text { aeroponic } \\
\text { indoor farming. }\end{array}$ & $\begin{array}{l}\text { Root morphology, } \\
\text { photoperiod cycles, } \\
\text { recycling of roots, } \\
\text { microbial impact. }\end{array}$ & $\begin{array}{l}\text { Covers in-depth study on } \\
\text { use and conditions for } \\
\text { using aeroponic. }\end{array}$ & $\begin{array}{c}\text { Lacks study on important } \\
\text { cash crops such } \\
\text { as saffron. }\end{array}$ \\
\hline
\end{tabular}

\subsection{Aquaponics}

Aquaponics refers to the combination of animal culture and plant cultivation for the mutual relationship of both. This symbiotic relationship results in water conditioning for aquatic life and oxygenated water recirculation for plants [52,53]. Researchers have designed aeroponic systems based on the monitoring and controlling of different parameters which have been compared in Table 2, highlighting their advantages and limitations.

Table 2. Comparison of existing Aquaponic models.

\begin{tabular}{|c|c|c|c|c|}
\hline Ref. & Nature of System & Parameters Used & Advantages & Drawbacks \\
\hline [54] & $\begin{array}{c}\text { Smart aquaponic system } \\
\text { based on Internet } \\
\text { of Things. }\end{array}$ & $\begin{array}{c}\text { Acidity, water } \\
\text { level, temperature. }\end{array}$ & $\begin{array}{l}\text { User friendly and } \\
\text { real-time results. }\end{array}$ & $\begin{array}{l}\text { Throughput index lag; } \\
\text { decreasing packet loss } \\
\text { and delay. }\end{array}$ \\
\hline [55] & $\begin{array}{l}\text { Towards automated } \\
\text { aquaponics: a review on } \\
\text { monitoring, IoT, and } \\
\text { smart systems. }\end{array}$ & $\begin{array}{c}\text { Temperature, } \mathrm{pH}, \\
\text { moisture, alkalinity, } \\
\text { dissolved oxygen, water } \\
\text { hardness, relative } \\
\text { humidity, } \\
\text { and nitrification. }\end{array}$ & $\begin{array}{c}\text { In-depth technical } \\
\text { knowledge about } \\
\text { automation and use of } \\
\text { IoT in } \\
\text { aquaponic systems. }\end{array}$ & Not implemented yet. \\
\hline [56] & $\begin{array}{c}\text { Smart aquaponics design } \\
\text { using Internet of } \\
\text { Things technology. }\end{array}$ & Temperature, light, $\mathrm{pH}$. & $\begin{array}{c}\text { Good for small } \\
\text { scale applications. }\end{array}$ & $\begin{array}{l}\text { Not implemented for } \\
\text { scalable networks. }\end{array}$ \\
\hline [57] & $\begin{array}{l}\text { Smart aquaponic with } \\
\text { monitoring and control } \\
\text { system based on the IoT. }\end{array}$ & $\begin{array}{l}\text { Temperature, humidity, } \\
\text { soil moisture. }\end{array}$ & $\begin{array}{l}\text { Automatic and manual } \\
\text { modes of operation. }\end{array}$ & $\begin{array}{l}\text { Average manual control } \\
\text { speed is } 5 \mathrm{~s} .\end{array}$ \\
\hline
\end{tabular}

Ulum et al., proposed a smart aquaponics system using the IoT in which water is allowed to flow after regular intervals. Various parameters such as acidity, water level, temperature, and the feed used for fishes were monitored in real time using a mobile-based application. All the data was collected on the Ubuntu cloud for future use. The sensors 
used to control the $\mathrm{pH}$, temperature, and other parameters worked fine and gave real-time results [54].

Yanes et al., proposed an automated aquaponic system with efficient use of water and minimal use of pesticides and fertilizers, making use of the Green IoT. The paper also provides a systematic literature review of different sensors used in an aquaponic environment. The system focuses on monitoring and controlling different parameters such as temperature, $\mathrm{pH}$, moisture, alkalinity, dissolved oxygen, water hardness, relative humidity, and nitrification, etc. The system focuses on analyzing each parameter responsible for growth. The paper gave in-depth technical knowledge about automation and the use of the IoT in such systems [55].

Hardyanto et al., proposed a smart aquaponic approach using the IoT in which plants filter out the water for aquatic animals and plants derive nutrition from aquatic animal extracts. The system contains actuators and sensors which monitor and control the chamber using mobile phones. The results of this system show that it is a great fit for small-scale applications [56].

Vernandhes et al., designed a smart aquaponics system that monitors and controls temperature, humidity, soil moisture, etc. using the IoT. The system has two modes of working, automatic and manual, and the average manual control speed is five seconds [57].

\subsection{Hydroponics}

Hydroponics involves the use of water as a medium for the cultivation of crops. The IoT can be used in hydroponics to control and monitor different agronomical variables, creating a smart environment for the cultivation of saffron. The network of sensors used in the IoT can continuously monitor and control crop health and growth. All the essential macro and micronutrients required for the saffron crop, such as $\mathrm{Ca}, \mathrm{N}, \mathrm{Mg}, \mathrm{S}, \mathrm{K}, \mathrm{P}$ and $\mathrm{Cu}$, $\mathrm{Fe}, \mathrm{B}, \mathrm{Mn}, \mathrm{Ni}$, respectively, are passed to the plant through channels or other mediums [58]. Agronomical variables for growth can be both monitored and controlled by farmers using application interfaces directly connected to the cloud storing real-time data. It also results in the improved quality of crops and eliminates the damage caused by parasites and rodents on crops by the use of controlled environments [59]. Based on the type of medium, hydroponic techniques are classified into several categories as shown in Figure 4 [35].

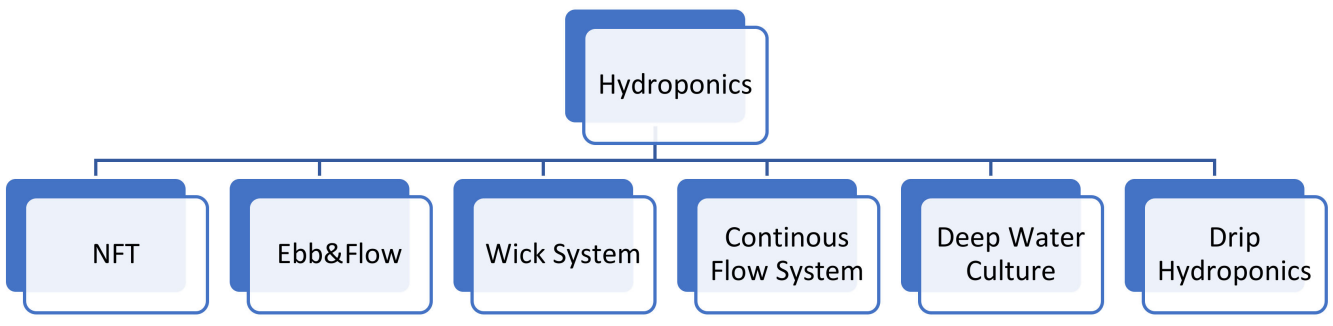

Figure 4. Different Hydroponic Approaches.

The NFT refers to the use of a small channel or tube for the continuous circulation of a nutrient solution through the array of plants. It is an electricity-based system with channels placed at an angle so that nutrients can be moved to higher segments also to facilitate nutrient movement [60-64].

The ebb and flow system uses the concept of flood and drains for the movement of nutrients. An air pump is used to deliver oxygen and nutrients to the roots of plants in cycles and, with the help of a timer, the excessive water is removed for the system to dry out. However, there is a lot of effort involved in the removal of damaged and leftover plants due to the widespread roots of the plants covering the whole tray, hence making it suitable only for the cultivation of small plants $[35,62,64]$.

Drip or trickle hydroponics is an active system that makes use of emitters sprinkling nutrient-rich solution at a very slow speed. It is mostly adopted for commercial hydroponic setups due to the controlled nutrient supply. This system is suitable for the cultivation of 
larger plants such as onions, melons, strawberries, cucumbers, and peas. The disadvantage of the system lies in its complexity for a small project [62-64].

The wick system is based on the capillary action of roots, and the nutrients from the reservoir reach the plants through wicks. It involves components such as an air pump, reservoir, wick, growing medium, and the plant. It is very easy to set up and requires minimal maintenance. It is suitable for smaller plants such as herbs that do not require much water $[62,64]$.

The continuous flow system also recycles and reuses nutrient-rich water for plant growth. The nutrient solution is continuously passed through a pipe to let the plants absorb the required water for growth $[64,65]$.

Deep/direct water culture is one of the effective hydroponic systems which involves continuous reimbursement of plant roots in a nutrient and oxygen-rich solution. The quantity of water required for this is large in order to maintain nutrient stability. This system requires an air stone and air pump to continuously run to prevent oxygen deficit and the waterlogging of roots. This system is best for the growth of herbs and small plants such as tomatoes, peppers, and lettuces which do not require flowering. This system can be used in scenarios where a maximum yield is the goal, as it accelerates the plant growth rate by double. The limitations of this approach are the possibility of a complete failure due to the failure of the air pump leading to the oxygen starvation of all the plants and the difficulty of maintaining the nutrient concentration of solution $[64,66]$.

Different researchers have designed hydroponic systems based on the monitoring and controlling of different parameters which have been compared in Table 3, highlighting their advantages and limitations.

Table 3. Comparison of existing hydroponic models.

\begin{tabular}{|c|c|c|c|c|}
\hline Ref. & Nature of System & Parameters Used & Advantages & Drawbacks \\
\hline [17] & $\begin{array}{l}\text { Automation system } \\
\text { hydroponic using smart } \\
\text { solar power plant unit. }\end{array}$ & $\begin{array}{l}\text { Temperature, humidity, } \\
\text { and } \mathrm{pH} .\end{array}$ & $\begin{array}{l}\text { Controls temperature } \\
\text { and humidity effectively. }\end{array}$ & $\begin{array}{c}\text { No proper } \mathrm{pH} \\
\text { monitoring. } \\
\text { Lacks proper } \\
\text { measurement of nutrients } \\
\text { in nutrient tank. }\end{array}$ \\
\hline [35] & $\begin{array}{l}\text { Hydroponic growth of } \\
\text { saffron (ebb and flow } \\
\text { vertical system) }\end{array}$ & $\begin{array}{l}\text { Temperature, humidity, } \\
\text { oxygen concentration. }\end{array}$ & $\begin{array}{l}\text { Detailed analysis of all } \\
\text { the hydroponic } \\
\text { approaches present. }\end{array}$ & Not implemented. \\
\hline [66] & $\begin{array}{l}\text { Hydroponic forcing } \\
\text { of saffron. }\end{array}$ & $\begin{array}{l}\text { Light intensity, } \\
\text { temperature. }\end{array}$ & Increased crop yield. & $\begin{array}{l}\text { Costly. } \\
\text { Flowering in } \\
\text { selective plants. }\end{array}$ \\
\hline [67] & $\begin{array}{c}\text { Saffron by } \\
\text { vegetative growth. }\end{array}$ & All. & $\begin{array}{l}\text { The sizes of flowers and } \\
\text { stigmas were } \\
\text { considerably improved. }\end{array}$ & $\begin{array}{l}\text { Lack of use of } \\
\text { technologies. } \\
\text { Good flowering in } \\
\text { limited plants. }\end{array}$ \\
\hline [68] & $\begin{array}{c}\text { Growth of saffron in } \\
\text { aeroponics } \\
\text { and hydroponics. }\end{array}$ & $\begin{array}{l}\text { Temperature, humidity, } \\
\text { and } \mathrm{pH} .\end{array}$ & $\begin{array}{l}\text { Increased yield. } \\
\text { Good quality. } \\
\text { Implemented in } \\
\text { real time. }\end{array}$ & $\begin{array}{l}\text { Development of } \\
\text { contractile roots. } \\
\text { Plants not able to get full } \\
\text { nutrients due to } \\
\text { short roots. }\end{array}$ \\
\hline [69] & $\begin{array}{l}\text { Internet of Things } \\
\text { application for } \\
\text { hydroponics } \\
\text { plant-monitoring system. }\end{array}$ & $\begin{array}{l}\mathrm{pH} \text {, temperature, liquid } \\
\text { level, light intensity. }\end{array}$ & $\begin{array}{l}\text { Uses renewable sources } \\
\text { of energy. }\end{array}$ & $\begin{array}{l}\text { Considers only a few } \\
\text { parameters of growth. } \\
\text { Focusses only on } \\
\text { monitoring } \\
\text { agronomical parameters. }\end{array}$ \\
\hline
\end{tabular}


Table 3. Cont.

\begin{tabular}{|c|c|c|c|c|}
\hline Ref. & Nature of System & Parameters Used & Advantages & Drawbacks \\
\hline [70] & $\begin{array}{l}\text { Smart farm hydroponics } \\
\text { system using wireless } \\
\text { sensor networks and the } \\
\text { Internet of Things. }\end{array}$ & $\begin{array}{l}\text { Temperature, } \\
\text { humidity, } \\
\text { pH. }\end{array}$ & $\begin{array}{l}\text { Provides monitoring and } \\
\text { control of parameters } \\
\text { for growth. }\end{array}$ & Not implemented yet. \\
\hline [71] & $\begin{array}{l}\text { Internet of Things for } \\
\text { planting in a smart-farm- } \\
\text { hydroponics style. }\end{array}$ & $\begin{array}{l}\text { Temperature, } \\
\text { humidity. }\end{array}$ & $\begin{array}{l}\text { Covers vast scope of the } \\
\text { IoT in } \\
\text { agricultural domains. }\end{array}$ & Not implemented yet. \\
\hline
\end{tabular}

The hydroponic system developed by Jurnal et al. [17] aims at improving the energy efficiency of the system. The system is designed to use solar energy for running the hydroponic system. Moreover, the system focuses on controlling and monitoring the parameters of growth in a hydroponic chamber. The prototype designed can control and monitor only a few parameters, such as temperature, humidity, and $\mathrm{pH}$, and is not specifically designed for saffron.

Khan et al. [35] proposed a home-based hydroponic system using ebb and flow for the cultivation of saffron. The authors have come up with a comparison based on the performance and cost of various present hydroponic approaches. The proposed system uses ebb tables, a water controlling system, a fertilizer system, and a ventilation system.

Schroeder et al. [66] used a growth chamber for saffron cultivation by using four different environments, namely organic layer, pin tray, control group, and hydroponic system environments. The vertical hydroponic system developed consisted of LED lighting and temperature regulators. The saffron plants were first cultivated in the field until flowering and then transferred to the growth chamber. Though the crop yield increased, the system incurred high costs. It was also not implemented using the IoT to give better results. Moreover, the authors stated that flowering did not occur in all the plants.

Fallahi et al. [67] explain in their paper that saffron cultivation was increased by using the concept of transplanting the corms which flowered earlier to provide better results. The observations from the experiment indicated that the sizes of the flowers and stigmas were considerably improved.

Souret et al. [68], in their paper, studied saffron cultivation in various environments such as natural, hydroponic, and aeroponics. It was found that the aeroponic and hydroponic approaches yielded better results as compared to the natural. However, the quality of the saffron remained the same in all three cultures. However, there was a reduction in root size in the aeroponic and the hydroponic cultures, which can harm the nutrient and water uptake. Moreover, there was the development of contractile roots, which plays a role in corm lowering.

Hidyanti et al. [69] have designed a hydroponic system as a solution to the decreasing Indonesian agricultural land. The designed hydroponic system focuses on growth parameters such as $\mathrm{pH}$, temperature, liquid level, and light intensity. There is the use of renewable solar energy for power supply. Various monitoring tools were used for analysis.

Boonnam et al. [70] have designed a hydroponic system by using the IoT and a wireless sensor network (WSN). Various important parameters such as light, humidity, and temperature were controlled by using this system. The data obtained from the sensors was continuously sent to the cloud for storage and future use. The parameters were controlled by using a mobile application.

Wongkoon et al. [71] have designed a model using the concept of the greenhouse using WSN. The paper focuses on many areas of agriculture requiring the use of the IoT, such as market availability, geospatial information, and weather prediction, but lacks a real-time implementation of the same.

There are various points of difference between the three hydroponic systems discussed above, which can be shown in tabular form $[35,62,64-66]$. Tables 4 and 5 present various points of difference between these three hydroponic systems, which can be shown as: 
Table 4. Comparison of NFT, ebb and flow, and drip.

\begin{tabular}{ccc}
\hline NFT & Ebb and Flow & Drip \\
\hline $\begin{array}{c}\text { Nutrient solution is passed through the } \\
\text { plants making a film. }\end{array}$ & $\begin{array}{c}\text { Uses flood and drain to deliver nutrients } \\
\text { and oxygen to plants. }\end{array}$ & $\begin{array}{c}\text { Continuous nutrient supply using } \\
\text { emitters for each plant in different pots. }\end{array}$ \\
\hline Water saving. & Uses a lot of water. & Limited water usage. \\
\hline Single-point failure if pump fails. & Single-point failure. & No single-point failure. \\
\hline Suitable for medium plants. & $\begin{array}{c}\text { Suitable for plants requiring a lot of water } \\
\text { for growth such as spinach and lettuce. }\end{array}$ & $\begin{array}{c}\text { Suitable for large gardens having } \\
\text { different plants. }\end{array}$ \\
\hline $\begin{array}{c}\text { Expensive and complex only } \\
\text { at beginning. }\end{array}$ & $\begin{array}{c}\text { Complex management due to smaller } \\
\text { distance between plants. }\end{array}$ & $\begin{array}{c}\text { Cost friendly and low maintenance for } \\
\text { larger projects. }\end{array}$ \\
\hline
\end{tabular}

Table 5. Comparison of wick, continuous flow and deep culture.

\begin{tabular}{lll}
\hline Wick & Continuous Flow & Deep Culture \\
\hline $\begin{array}{l}\text { Passing nutrient solution to roots using } \\
\text { wicks based on capillary action. }\end{array}$ & $\begin{array}{l}\text { Continuous passing of nutrient solution } \\
\text { through roots after fixed intervals. }\end{array}$ & $\begin{array}{l}\text { Continuous immersing of plant roots in } \\
\text { nutrient solution. }\end{array}$ \\
\hline Consumes very little water. & Consumes more water than wick system. & Consumes a lot of water. \\
\hline No single-point failure. & Single-point failure. & $\begin{array}{l}\text { Difficult to maintain nutrient } \\
\text { concentration in solution. } \\
\text { Single-point failure if air pump or air } \\
\text { stone fails. }\end{array}$ \\
\hline $\begin{array}{l}\text { Ideal for smaller plants with low } \\
\text { water requirements. }\end{array}$ & $\begin{array}{l}\text { Ideal for plants having water } \\
\text { requirements in intervals. }\end{array}$ & $\begin{array}{l}\text { Suitable for plants requiring lot of water } \\
\text { for growth. }\end{array}$ \\
\hline Economical. & Costly. & Costly. \\
\hline
\end{tabular}

\subsection{Discussion}

The use of any hydroponic technique out of the six listed above depends on several factors, such as root anatomy, plant structure, water requirement, and suitability in a particular environment $[51,71]$. Considering the water consumption, cost, and anatomical factors of saffron related to root morphology studied from the literature, NFT was considered to be the best practice for the growth of saffron hydroponically [66-69,72]. The most famous hydroculture approach being followed is hydroponics, due to its low cost and having a majority of benefits $[36,37,51,72]$. Aeroponics is best suited for plants that are small and not propagated by using roots. Tomatoes, lettuce, herbs, celery, and leafy greens are some of the plants cultivated by using aeroponics [38,44,72]. On the other hand, aquaponics is best suited for plants having shallow roots, such as sweet corn, beets, onion, cucumbers, and radishes. Plants that need an uninterrupted water supply are an excellent choice to be grown in such medium [R, S]. Saffron is a plant with a short height, moderate water requirement, and is propagated using roots, hence an excellent choice for cultivating it in an artificial environment is hydroponics $[20,22,23,73]$. Hydroponics is also widely used and preferred due to its low cost, low water consumption, improved yield, and quality $[36,37,73]$.

\section{Research Methodology}

In this section, we present a systematic literature review (SLR) method for categorizing various artificial approaches used for saffron cultivation using the IoT for current research. The following studied string words are used to determine important synonyms and keywords of the approaches:

- ("Saffron" OR “Cultivation" OR "IoT" OR "Saffron Cultivation" OR "Hydroponics") We created some technical questions (TQ) based on the scope of the precision farming in saffron cultivation using the SLR method:

- TQ1: What are the primary reasons for saffron decline? 
- TQ2: Which existing artificial techniques are used for saffron production?

- TQ3: Which agronomical variables are considered for increasing the yield?

To refine the key research, the addition and removal techniques are employed as paper screening in the final paper selection. Due to the tremendous potential of Web of Science journals, research articles that are indexed in the Web of Science and ISI proceedings with the peer-reviewed process are considered for saffron cultivation in the IoT. Some of the paper's drawbacks are as follows: (1) non-English research articles are not considered in the SLR method and (2) low-quality conferences with fewer than four pages are not considered in the SLR method. Finally, we chose 100 papers to respond to our technical queries. Scientific publishers such as Google Scholar, IEEE, Elsevier, Springer, ACM, and Wiley publish a wide range of research studies each year, as seen in Figure 5. Figure 6 depicts the addition and rejection flowchart for the final selection.

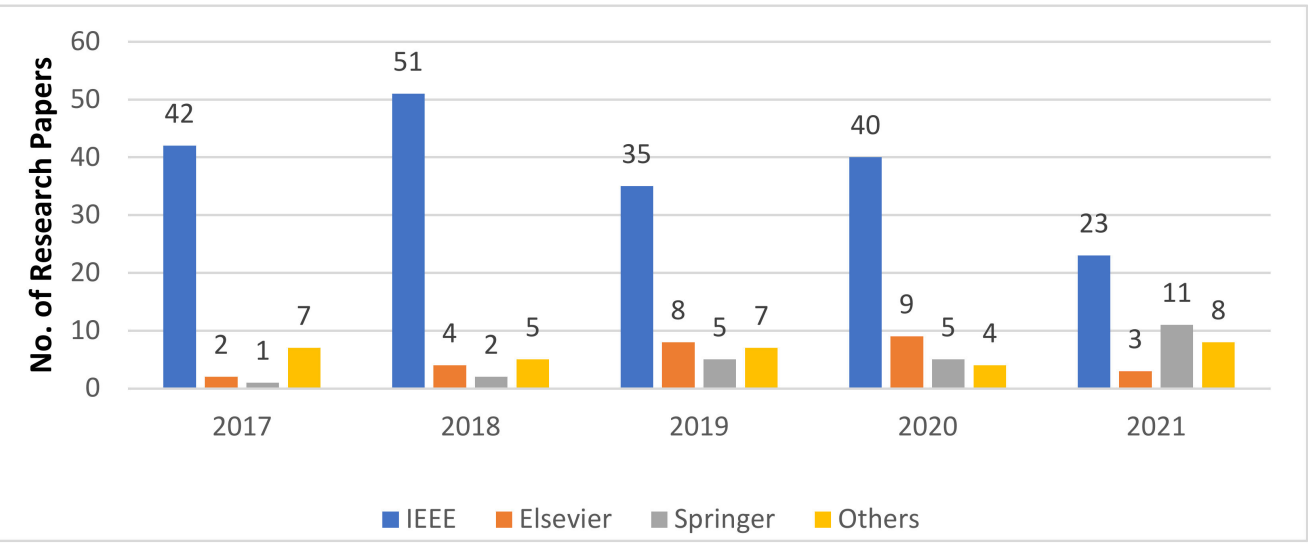

Figure 5. Yearlyresearch paper publications by publishers.

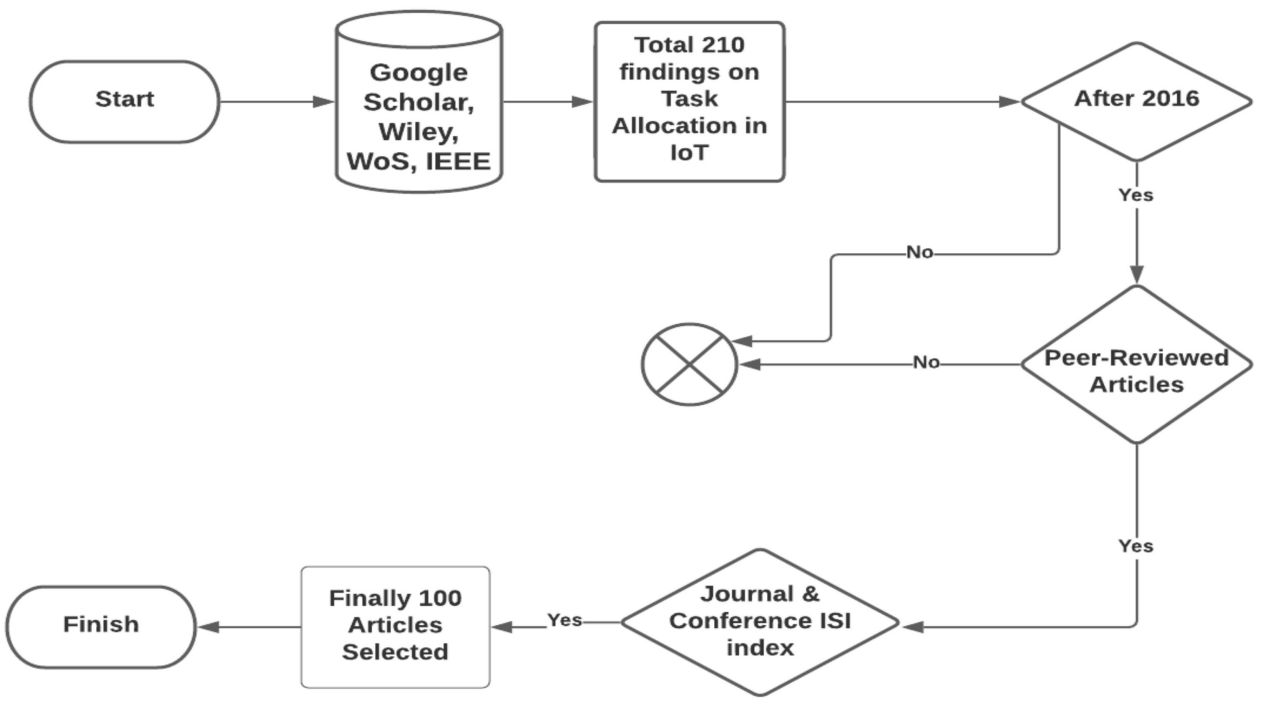

Figure 6. Paper selection procedure.

\section{Summary and Discussion}

This section shows an analytical examination of the critical factors identified by different researchers and used for saffron cultivation, such as reasons for the decline, artificial techniques used, and agronomical variables considered. The analytical examination and reports are based on the existing TQs in Section 3:

- TQ1: What are the primary reasons for saffron decline?

Figure 7 represents a statistical comparison of various issues related to the saffron decline. In this, we consider five different issues. The non-availability of good quality 
corms has the highest percentage with $37 \%$, followed by nutrient-deficient soil with $20 \%$, and a lack of efficient post-harvest practices with $18 \%$.

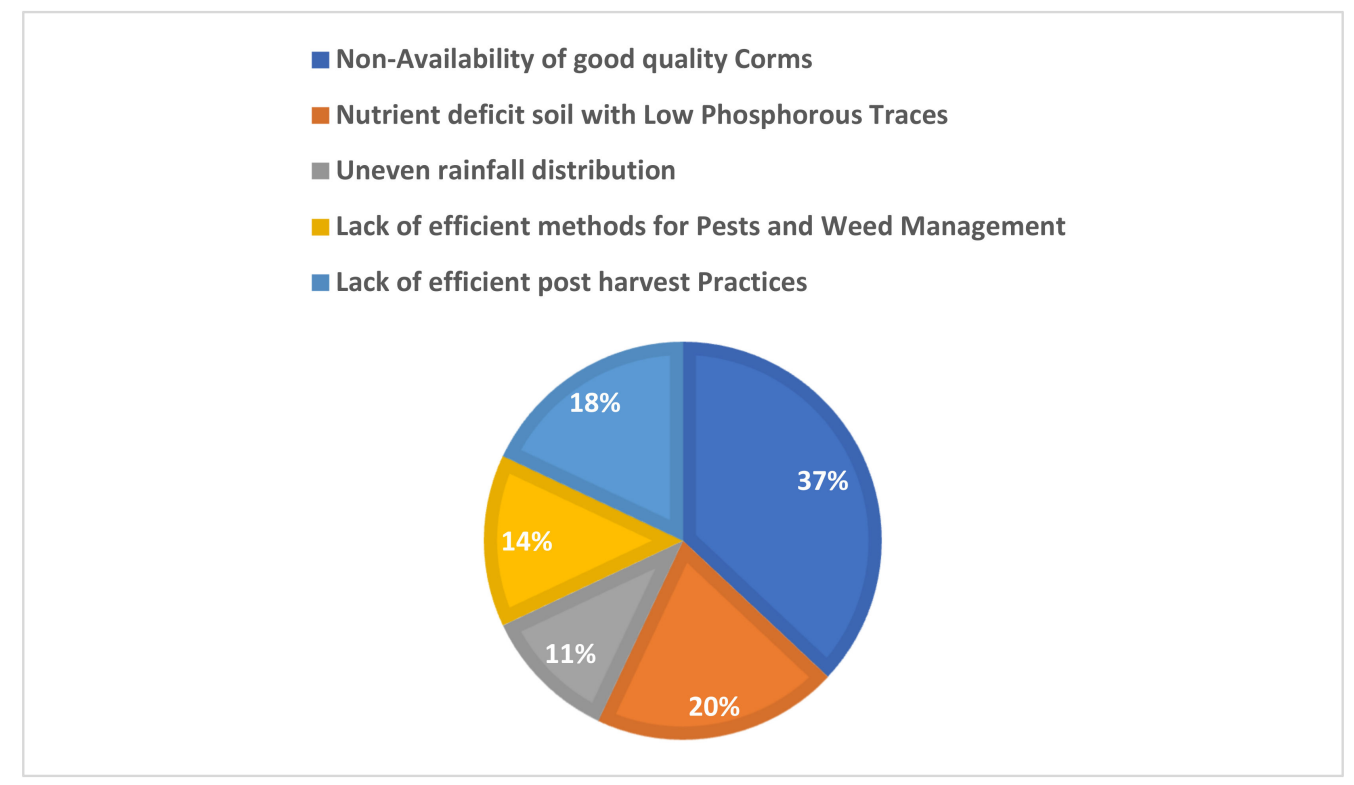

Figure 7. Reasons for saffron decline.

- TQ2: Which existing artificial techniques are used for saffron production?

Figure 8 represents a statistical comparison of various artificial approaches used for saffron cultivation. For this analysis, we considered 22 different research papers studying the use of the IoT for artificial techniques. Out of those, 11 papers were dedicated to hydroponics models, 9 papers to aeroponics, and only 4 papers to aquaponics approach.

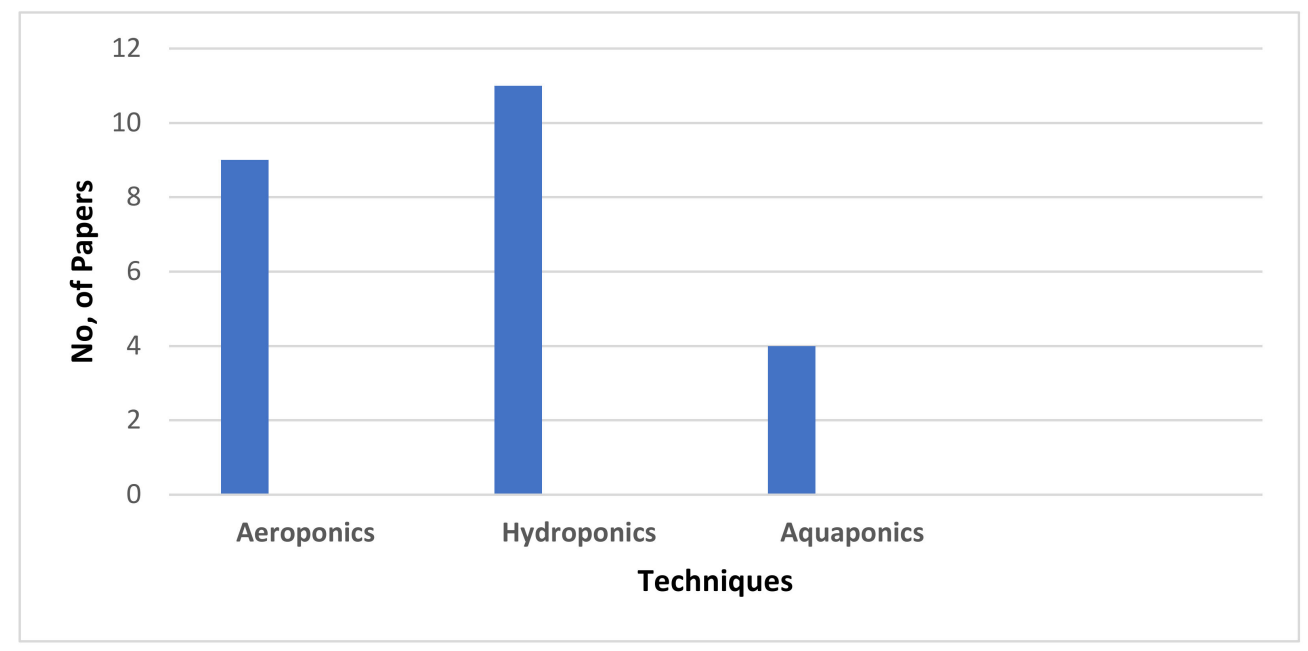

Figure 8. Artificial techniques used for saffron cultivation.

- TQ3: Which agronomical variables are considered for increasing the yield?

In Figure 9, the analytical report on agronomical variables depicts that the temperature parameter is used most in increasing the yield of the saffron with $27 \%$, followed by corm size with $21 \%$, and rainfall with $19 \%$. 


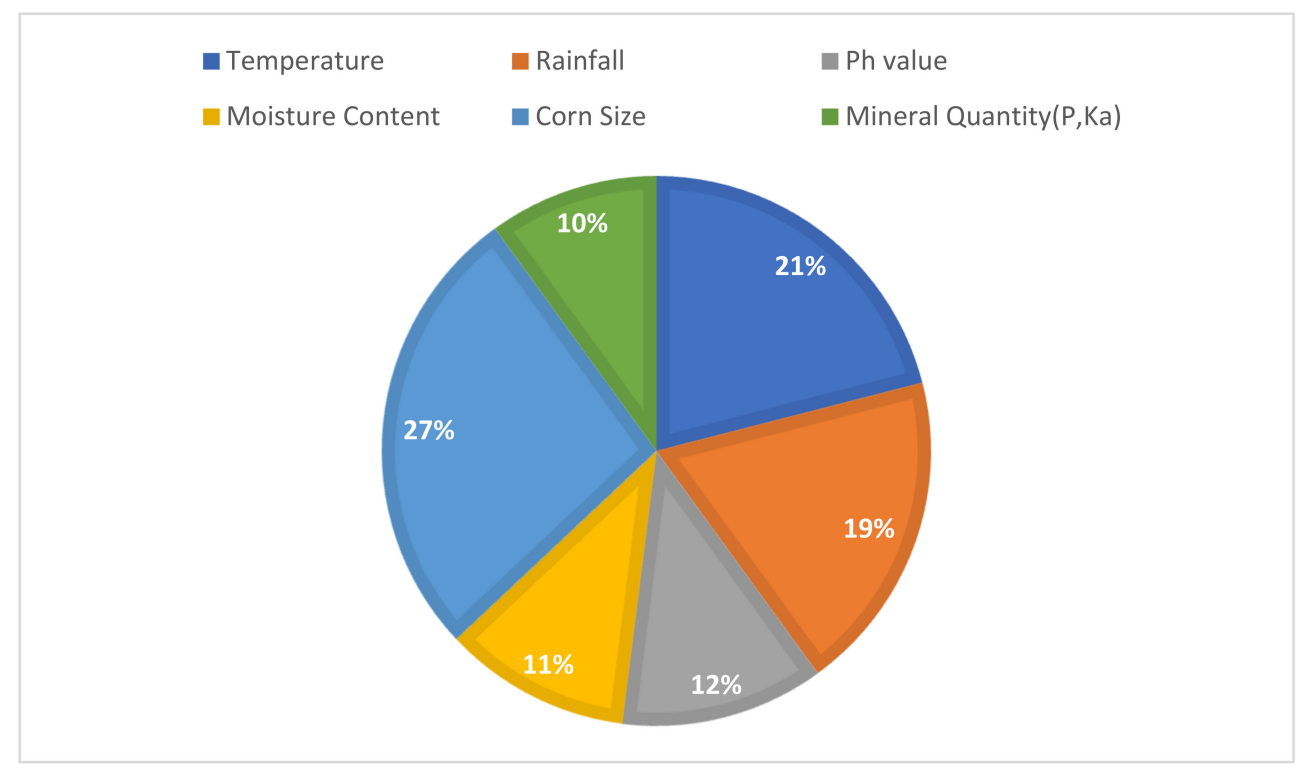

Figure 9. Agronomical variables of saffron as per the priority.

\section{Smart Hydroponic System for Saffron Cultivation}

The smart hydroponic system as shown in Figure 10 has been proposed after studying all the existing hydroponic systems and analyzing their features and drawbacks. It aims to enhance saffron yield and quality in an artificial medium by using cost-effective and renewable energy sources [17]. The proposed system aims to use renewable sources of energy such as solar and water so that it can work in places with a scarcity of electricity. The hydroponic approach used is NFT due to its reliability and water-recycling capabilities.

The system consists of a smart power supply source, nutrient solution tank, growth chamber, smart corm basket, user interface, and cloud data storage for analysis and future use.

Once the power supply mode is selected automatically, the sensors in the nutrient tank are activated. Different parameters related to the nutrient solution, such as $\mathrm{pH}$, turbidity, temperature, and the concentration of minerals, are continuously sent to the growth chamber, monitored, and shared on the user device as well as the cloud for future use and controlling the parameters. The water stream, rich in the micro and macronutrients required for saffron cultivation, is continuously circulated through the growth chamber. The corms are selected based on their mass and size by the smart basket, which is equipped with load sensors, to maximize the saffron yield and enhance the quality. The corms with weights $<2$ gare discarded as they do not flower at all. Only the corms having weights and diameters $>10 \mathrm{~g}$ are planted [20]. The best quality corms are planted after passing them through a fungicide solution to protect them from fungal infections [22]. The nutrient solution tank is equipped with various sensors, an air pump, and an air stone. The air pump passes the nutrient solution continuously through the growth chamber while the air stone is used to keep the presence of oxygen high in the solution provided. Ultrasonic sensors are used to calculate the desired space between two saffron plants in the growth chamber for plantation [20]. The final stage of cultivation occurs after the flowering of plants and the separation of stigmas from other parts. The obtained stigmas can be dried with 30 percent moisture remaining to maximize the value of the obtained crop.

The working of the system and the process of communication between different units can be clearly explained using a block diagram as shown in Figure 11. 


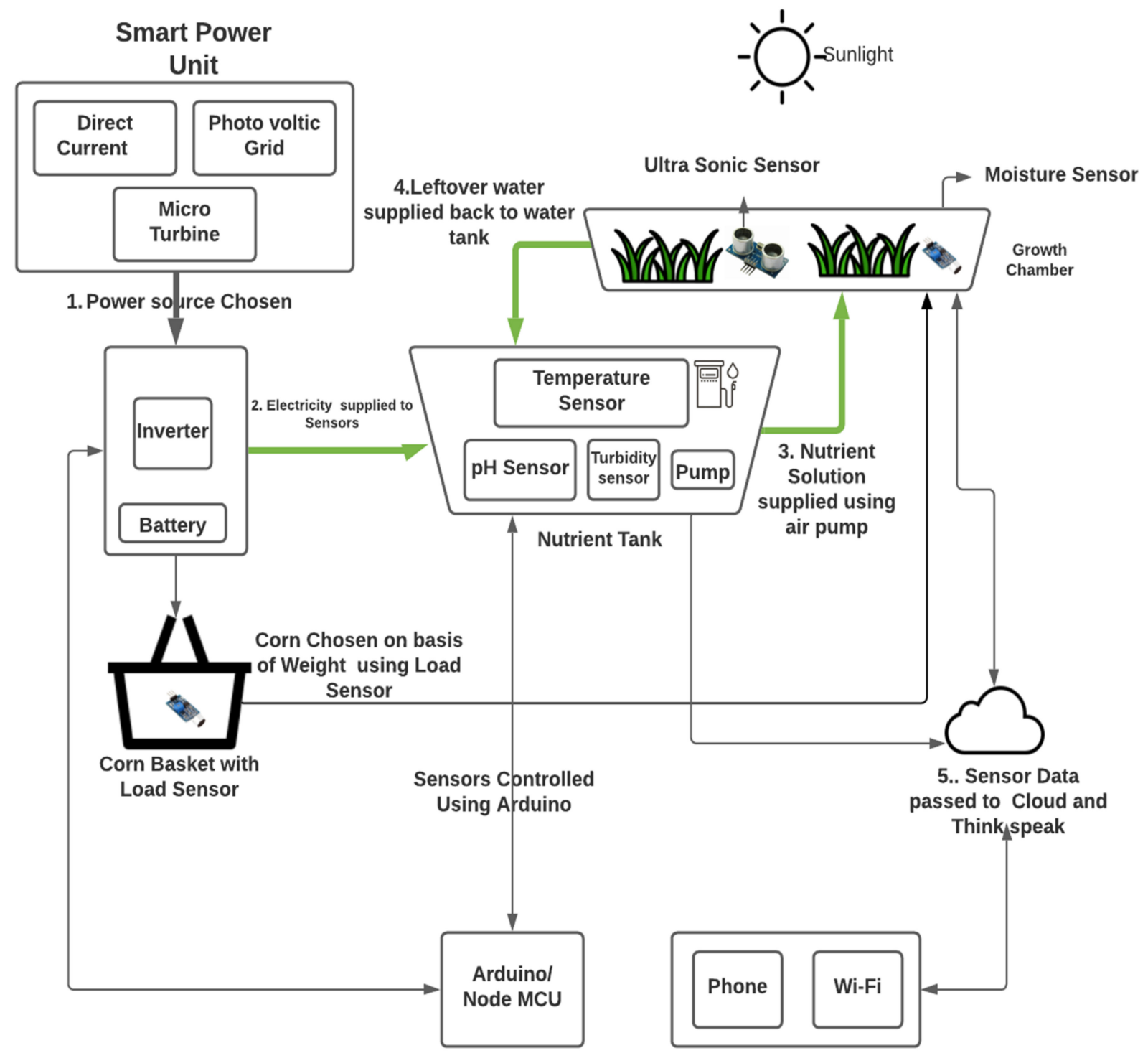

Figure 10. Layout of the smart hydroponic system for saffron cultivation.

The system consists of three components:

Power Unit: Due to the high energy consumption by various sensor devices, there is a great need for the use of renewable sources of energy such as solar energy, wind energy, and hydro energy. This will make the designed hydroponic system more sustainable and cost friendly. The power unit of the system consists of an array of photovoltaic cells, microturbines, a power supply, voltage sensors, controller, relays, and a battery for the storage of energy, so that the system is equipped with all the options of energy consumption and the user can switch between the alternatives using relays and switches. The photovoltaic cell array is used to convert solar energy to electricity, while microturbines help in the generation of hydroelectricity. In case of the absence of both, the power supply can also be used to supply the electricity used. The battery, which will be used for the storage of energy, will be a lithium battery depending on the size of the system, used devices, and the number of sensors deployed, which enables the hydroponic system to run for hours in case of a power failure. The inverter is used for converting DC to AC.

Sensor Unit: It consists of an array of sensors that have been used depending on the controlling and monitoring of various agronomical variables of saffron. The turbidity sensor is used to check the cleanliness of the nutrient solution and detect the presence of any unwanted waste materials in the nutrient solution tank. Gas sensors help to measure 
the oxygen levels in the growth chamber so that the plants don't suffer a lack of oxygen. Pressure sensors and flow sensors guide the user regarding the flow of the nutrient solution through the growth chamber. Other sensors used include temperature, $\mathrm{pH}$, light, humidity, and load sensors. Load sensors are used to identify the corms suitable in size and mass for cultivation.

Processing and Analyzing Unit: All the sensor data is shared with the microcontroller and Node MCU for analysis. All the parameters of growth can be monitored and controlled by Arduino and Node MCU. Node MCU is an open-source platform that replaces complex application programming interfaces (API) and uses the ESP8266 Wi-Fi module. The ESP8288 module, being very small in size, can sense the data from various sensor nodes wirelessly without any failures [72]. This unit is also connected to the graphical user interface and the Thing Speak platform, which is an online platform for data aggregation and visualization. It provides instant access to the user, and the user can take corresponding actions using mobile apps through their smartphones. The IoT protocols used for the data transfer within the network are CoAP (Constrained Application Protocol) and STOMP (Simple Text Oriented Messaging Protocol). CoAP and STOMP can be used for data transfer in different applications, such as smart healthcare and smart education, due to the security offered wirelessly using other technologies such as artificial intelligence and fuzzy logic [73-86].

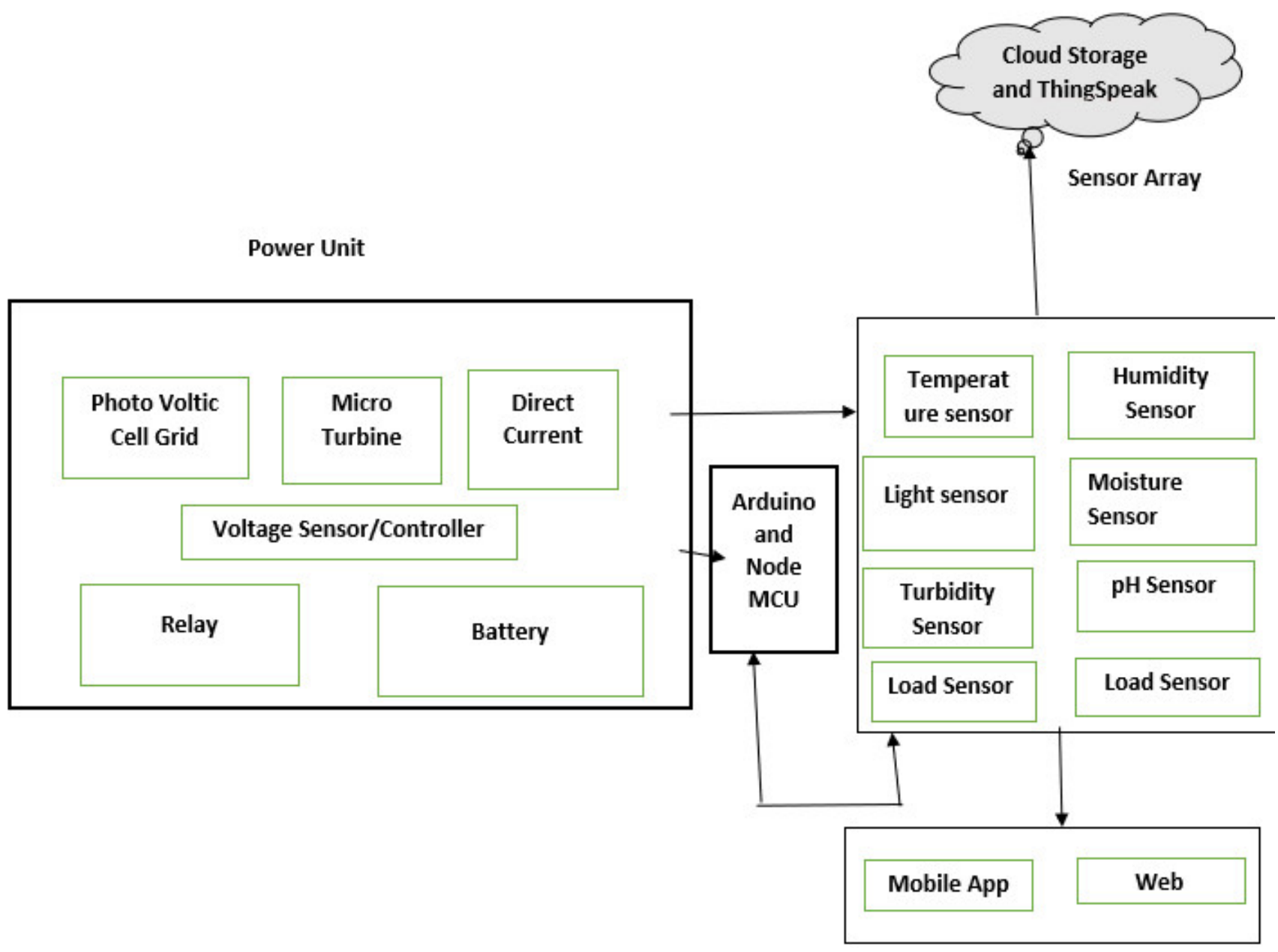

User Display and control

Figure 11. Block diagram of the proposed hydroponic system. 


\section{Conclusions}

This paper focuses on providing a systematic literature review of all the artificial approaches which can be used for saffron cultivation. Various artificial approaches for saffron cultivation were reviewed in general but with a focus primarily on hydroponic approaches. Important issues and the suitability of different approaches in hydroponics were also highlighted along with the major agronomical variables required for saffron growth. Different IoT-based hydroponic models developed by different researchers in this area were studied. The proposed smart hydroponic system for saffron cultivation was also presented. As per the literature review, it was observed that major reasons for the decline in saffron cultivation include the absence of good quality corms, water deficiency, undetected nutrient deficiency, and fungal diseases. It was observed that there was not much research carried out on the use of smart sensors and devices for improving saffron cultivation conditions. Out of various IoT-based models using aeroponics, aquaponics, and hydroponics for the cultivation of saffron, 22 models were found to be eligible for comparative study. It was also found that, out of 100 research articles studied, only 25 entirely focused on saffron cultivation. The future scope of this paper will be the implementation of the proposed system.

Author Contributions: Conceptualization, D.G.; Data curation, K.K.; Resources, H.M.; Investigation, K.G.; Methodology, S.J. and G.D.; Project Administration, H.M. and M.A.I.; Funding acquisition, M.A.I.; Formal Analysis, W.V. All authors have read and agreed to the published version of the manuscript.

Funding: This work was financially supported by the Malaysian Ministry of Higher Education through FRGS grant FRGS/1/2020/TK0/UM/02/33. This research is also funded by the Universiti Malaya Research Grant (RU013AC-2021).

Institutional Review Board Statement: Not applicable.

Informed Consent Statement: Not applicable.

Data Availability Statement: Not applicable.

Conflicts of Interest: The authors declare no conflict of interest.

\section{References}

1. Dolli, M.; Divya, K.S. A study on present indian agriculture: Status, Importance, and Role in Indian Economy. ZENITH Int. J. Multidiscip. Res. 2020, 10, 30-34.

2. Gubbi, J.; Buyya, R.; Marusic, S.; Palaniswami, M. Internet of Things (IoT): A vision, architectural elements, and future directions. Future Gener. Comput. Syst. 2013, 29, 1645-1660. [CrossRef]

3. Alexandratos, N.; Bruinsma, J. World Agriculture towards 2030/2050: The 2012 Revision. Available online: https:/ /www.fao. org/global-perspectives-studies/resources/detail/en/c/411108/ (accessed on 15 October 2021).

4. Lee, I.; Lee, K. The Internet of Things (IoT): Applications, investments, and challenges for enterprises. Bus. Horiz. 2015, 58, 431-440. [CrossRef]

5. Giupponi, L.; Ceciliani, G.; Leoni, V.; Panseri, S.; Guido, R.P.L.; Di Filippo, A.; Giorgi, A. Quality traits of saffron produced in Italy: Geographical area effect and good practices. J. Appl. Bot. Food Qual. 2019, 336-342. [CrossRef]

6. Wali, E.; Datta, A.; Shrestha, R.P.; Shrestha, S. Development of a land suitability model for saffron (Crocus sativus L.) cultivation in Khost Province of Afghanistan using GIS and AHP techniques. Arch. Agron. Soil Sci. 2016, 62, 921-934. [CrossRef]

7. Asiabani, N.; Rafiee, H.; Aminizadeh, M.; Mehrparvar Hosseini, E. Determining the Structure of Saffron Target Markets and Analyzing Its Impact on Iranian Exports. Saffron Agron. Technol. 2020, 8, 421-426.

8. Khajeh-Hosseini, M.; Fallahpour, F. Emerging innovation in saffron production. In Saffron; Woodhead Publishing: Cambridge, UK, 2020; pp. 205-216.

9. Caser, M.; Demasi, S.; Victorino, Í.M.M.; Donno, D.; Faccio, A.; Lumini, E.; Bianciotto, V.; Scariot, V. Arbuscular mycorrhizal fungi modulate the crop performance and metabolic profile of saffron in soilless cultivation. Agronomy 2019, 9, 232. [CrossRef]

10. Gokul, S.; Mulla, I.; Nagaraja, K.; Pramoth, S.; Revathi, G.P. Smart Hydroponic System Using IOT. In Proceedings of the International Conference on Innovative Computing \& Communication (ICICC), Banglore, India, 12 July 2021; Available online: https://ssrn.com/abstract=3884824 (accessed on 15 October 2021). [CrossRef]

11. Perera, C.; Zaslavsky, A.; Christen, P.; Georgakopoulos, D. Sensing as a service model for smart cities supported by internet of things. Trans. Emerg. Telecommun. Technol. 2014, 25, 81-93. [CrossRef] 
12. Jin, J.; Gubbi, J.; Marusic, S.; Palaniswami, M. An information framework for creating a smart city through internet of things. IEEE Internet Things J. 2014, 1, 112-121. [CrossRef]

13. Ghobaei-Arani, M.; Souri, A.; Rahmanian, A.A. Resource management approaches in fog computing: A comprehensive review. J. Grid Comput. 2019, 18, 1-42. [CrossRef]

14. Kour, K.; Gupta, D.; Gupta, K.; Bali, M.S. IoT: Systematic review, architecture, applications and dual impact on industries. IOP Conf. Ser. Mater. Sci. Eng. 2021, 1022, 012053. [CrossRef]

15. Chauhan, H.; Gupta, D.; Gupta, S.; Kumar, D. IOT-Based Electronic Ticket Device for Environmental Conservation Using GSM Module. In Proceedings of the Second International Conference on Information Management and Machine Intelligence, Virtual Event, 24-29 July 2021; Springer: Singapore, 2021; pp. 103-111.

16. Joshitha, C.; Kanakaraja, P.; Kumar, K.S.; Akanksha, P.; Satish, G. An eye on hydroponics: The IoT initiative. In Proceedings of the 2021 7th International Conference on Electrical Energy Systems (ICEES), Chennia, India, 11-13 February 2021; pp. 553-557.

17. Siregar, S.; Sari, M.I.; Jauhari, R. Automation system hydroponic using smart solar power plant unit. J. Teknol. 2016, 78. [CrossRef]

18. Majid, M.; Khan, J.N.; Shah, Q.M.A.; Masoodi, K.Z.; Afroza, B.; Parvaze, S. Evaluation of hydroponic systems for the cultivation of Lettuce (Lactuca sativa L., var. Longifolia) and comparison with protected soil-based cultivation. Agric. Water Manag. 2021, 245, 106572. [CrossRef]

19. Ali, A.; Hakim, I.A. An overview of the production practices and trade mechanism of saffron in Kashmir Valley (India): Issues and challenges. Pac. Bus. Rev. Int. 2017, 10, 97-106.

20. Husaini, A.M.; Hassan, B.; Ghani, M.Y.; Teixeira da Silva, J.A.; Kirmani, N.A. Saffron (Crocus sativus Kashmirianus) cultivation in Kashmir: Practices and problems. Funct. Plant Sci. Biotechnol. 2010, 4, 108-115.

21. Hassan-Beygi, S.R.; Ghanbarian, D.; Kianmehr, M.H.; Farahmand, M. Some physical properties of saffron crocus corm. Cercet. Mold. 2010, 141, 17-29.

22. Nehvi, F.A.; Yasmin, S. Policy and research initiatives for promotion of saffron farming system and trade for doubling farmers' income. J. Hortic. Postharvest Res. 2021, 4, 89-110.

23. Taufique, M.; Khursheed, V.; Suhail Ahmad, W. Saffron production in Jammu and Kashmir: Problems and prospects. IJSRD-Int. J. Sci. Res. Dev. 2017, 5, 2321-2613.

24. Why Kashmir's Saffron Fields Are Shrinking (thewire.in). Available online: https://thewire.in/agriculture/kashmir-saffronflower-cultivation (accessed on 15 October 2021).

25. Fallahi, H.R.; Aghhavani-Shajari, M.; Sahabi, H.; Behdani, M.A.; Sayyari-Zohan, M.H.; Vatandoost, S. Influence of some pre and post-harvest practices on quality of saffron stigmata. Sci. Hortic. 2021, 278, 109846. [CrossRef]

26. Aghaei, Z.; Jafari, S.M.; Dehnad, D.; Ghorbani, M.; Hemmati, K. Refractance-window as an innovative approach for the drying of saffron petals and stigma. J. Food Process Eng. 2018, 41, e12863. [CrossRef]

27. Sereshti, H.; Poursorkh, Z.; Aliakbarzadeh, G.; Zarre, S. Quality control of saffron and evaluation of potential adulteration by means of thin layer chromatography-image analysis and chemometrics methods. Food Control 2018, 90, 48-57. [CrossRef]

28. Li, S.; Xing, B.; Lin, D.; Yi, H.; Shao, Q. Rapid detection of saffron (Crocus sativus L.) Adulterated with lotus stamens and corn stigmas by near-infrared spectroscopy and chemometrics. Ind. Crops Prod. 2020, 152, 112539. [CrossRef]

29. Mehmood, Y.; Kumar, P. Status of Agriculture Production and Productivity in Jammu and Kashmir. 2020. Available online: https: / / ssrn.com/abstract=3643764 (accessed on 15 October 2021).

30. Kumar, M.S. Design and developmeent of automatic robotic system for vertical hydroponic farming using iot and big data analysis. Turk. J. Comput. Math. Educ. 2021, 12, 1597-1607.

31. Shrivastava, A.; Nayak, C.K.; Dilip, R.; Samal, S.R.; Rout, S.; Ashfaque, S.M. Automatic robotic system design and development for vertical hydroponic farming using IoT and big data analysis. Mater. Today Proc. 2021. [CrossRef]

32. Garg, D.; Khan, S.; Alam, M. Integrative use of IoT and deep learning for agricultural applications. In Proceedings of ICETIT 2019; Springer: Cham, Switzerland, 2020; pp. 521-531.

33. Zsombik, L.; Hanász, A.; Sipos, T.; Basal, O.; Magyar-Tábori, K. Seedling morphology of different wheat genotypes at early stages under hydrocultural conditions. Acta Agrar. Debr. 2021, 249-254. [CrossRef]

34. DasGupta, A. Hydrocultural Histories and Narratives: Insights from the Sundarbans. Ecol. Econ. Soc. INSEE J. 2020, 3, 169-178. [CrossRef]

35. Khan, K.A. Hydroponically Growth of Saffron (Flow ebb Vertical System $530 \times 155$ ) Conceptto Design. Available online: https:/ / www.researchgate.net/publication/349915899_Hydroponically_Growth_of_Saffron_Flow_ebb_Vertical_System_53 0x155_ft_Concept_to_Design (accessed on 15 October 2021).

36. Çalışkan, M.E.; Yavuz, C.; Yağız, A.K.; Demirel, U.; Çalışkan, S. Comparison of aeroponics and conventional potato mini tuber production systems at different plant densities. Potato Res. 2021, 64, 41-53. [CrossRef]

37. Bhakar, V.; Kaur, K.; Singh, H. Analyzing the Environmental Burden of an Aquaponics System using LCA. Procedia CIRP 2021, 98, 223-228. [CrossRef]

38. Lakhiar, I.A.; Gao, J.; Syed, T.N.; Chandio, F.A.; Buttar, N.A. Modern plant cultivation technologies in agriculture under controlled environment: A review on aeroponics. J. Plant Interact. 2018, 13, 338-352. [CrossRef]

39. Li, Q.; Li, X.; Tang, B.; Gu, M. Growth responses and root characteristics of lettuce grown in aeroponics, hydroponics, and substrate culture. Horticulturae 2018, 4, 35. [CrossRef] 
40. Tunio, M.H.; Gao, J.; Shaikh, S.A.; Lakhiar, I.A.; Qureshi, W.A.; Solangi, K.A.; Chandio, F.A. Potato production in aeroponics: An emerging food growing system in sustainable agriculture for food security. Chil. J. Agric. Res. 2020, 80, 118-132. [CrossRef]

41. Lucero, L.; Lucero, D.; Ormeno-Mejia, E.; Collaguazo, G. Automated aeroponics vegetable growing system. In Proceedings of the Case Study Lettuce, IEEE ANDESCON, Quito, Ecuador, 13 October 2020; pp. 1-6. [CrossRef]

42. Kerns, S.C.; Lee, J.L. Automated aeroponics system using IoT for smart farming. In Proceedings of the 8th International Scientific Forum, ISF, Pembroke, NC, USA, 7-8 September 2017; pp. 7-8.

43. Francis, F.; Vishnu, P.L.; Jha, M.; Rajaram, B. IOT-based automated aeroponics system. In Intelligent Embedded Systems; Springer: Singapore, 2018; pp. 337-345.

44. Juneja, S.; Juneja, A.; Dhiman, G.; Behl, S.; Kautish, S. An Approach for Thoracic Syndrome Classification with Convolutional Neural Networks. Comput. Math. Methods Med. 2021, 2021, 3900254. [CrossRef]

45. Jamhari, C.A.; Wibowo, W.K.; Annisa, A.R.; Roffi, T.M. Design and Implementation of IoT System for Aeroponic Chamber Temperature Monitoring. In Proceedings of the 2020 Third International Conference on Vocational Education and Electrical Engineering (ICVEE), Surabaya, Indonesia, 3-4 October 2020; pp. 1-4.

46. Mangaiyarkarasi, R. Aeroponics system for production of horticultural crops. Madras Agric. J. 2020, 107. [CrossRef]

47. Fallahi, H.R.; Abbasi Aval Bohlooli, S.; Noferesti, E.; Hoseini, S.M.; SeddighMakoo, S.; Moodi, M.; Khezri, M. Evaluation the possibility of saffron transplanting and corm production in soilless planting system. J. Saffron Res. 2020, 8, $269-284$.

48. Razavizadeh, B.M.; Arabshahi Delooei, N. Quantification of crocin, picrocrocin and safranal in saffron stigmas obtained from sounded corms with acoustic waves. Phytochem. Anal. 2021, 32, 1059-1066. [CrossRef]

49. Ebrahimi, M.; Pouyan, M.; Hoseini, S.; Shahi, T.; Ragh Ara, H. Effect of mother-corm weight on the yield, reproductive growth, apocarotenoid content and production of daughter corms in saffron aeroponic cultivation. J. Saffron Res. 2021. [CrossRef]

50. Salas, M.D.C.; Montero, J.L.; Diaz, J.G.; Berti, F.; Quintero, M.F.; Guzmán, M.; Orsini, F. Defining optimal strength of the nutrient solution for soilless cultivation of saffron in the Mediterranean. Agronomy 2020, 10, 1311. [CrossRef]

51. Eldridge, B.M.; Manzoni, L.R.; Graham, C.A.; Rodgers, B.; Farmer, J.R.; Dodd, A.N. Getting to the roots of aeroponic indoor farming. New Phytol. 2020, 228, 1183-1192. [CrossRef]

52. Baganz, G.F.; Junge, R.; Portella, M.C.; Goddek, S.; Keesman, K.J.; Baganz, D.; Staaks, G.; Shaw, C.; Lohrberg, F.; Kloas, W. The aquaponic principle-It is all about coupling. Rev. Aquac. 2021, 14, 252-264. [CrossRef]

53. Jordan, R.A.; Geisenhoff, L.O.; Oliveira, F.C.D.; Santos, R.C.; Martins, E.A. Yield of lettuce grown in aquaponic system using different substrates. Rev. Eng. E Ambient. 2018, 22, 27-31.

54. Ulum, M.; Ibadillah, A.F.; Alfita, R.; Aji, K.; Rizkyandi, R. Smart aquaponic system-based Internet of Things (IoT). J. Phys. Conf. Ser. 2019, 1211, 012047.

55. Yanes, A.R.; Martinez, P.; Ahmad, R. Towards automated aquaponics: A review on monitoring, IoT, and smart systems. J. Clean. Prod. 2020, 263, 121571. [CrossRef]

56. Hardyanto, R.H.; Ciptadi, P.W. Smart Aquaponics Design Using Internet of Things Technology. J. Phys. Conf. Ser. 2020, 835, 012026. [CrossRef]

57. Vernandhes, W.; Salahuddin, N.S.; Kowanda, A.; Sari, S.P. Smart aquaponic with monitoring and control system based on IoT. In Proceedings of the 2017 Second International Conference on Informatics and Computing (ICIC), Jayapura, Indonesia, 1-3 November 2017; pp. 1-6.

58. Trejo-Téllez, L.I.; Gómez-Merino, F.C. Nutrient solutions for hydroponic systems. In Hydroponics-A Standard Methodology for Plant Biological Researches; InTechOpen: Rijeka, Croatia, 2012; pp. 1-22.

59. Palande, V.; Zaheer, A.; George, K. Fully automated hydroponic system for indoor plant growth. Procedia Comput. Sci. 2018, 129, 482-488. [CrossRef]

60. De Castro Silva, M.G.; Hüther, C.M.; Ramos, B.B.; da Silva Araújo, P.; da Silva Hamacher, L.; Pereira, C.R. A Global Overview of Hydroponics: Nutrient Film Technique. Rev. Eng. Agric.-REVENG 2021, 29, 138-145.

61. Megantoro, P.; Ma'arif, A. Nutrient Film Technique for Automatic Hydroponic System Based on Arduino. In Proceedings of the 2020 2nd International Conference on Industrial Electrical and Electronics (ICIEE), Lombok, Indonesia, 20-21 October 2020; pp. 84-86.

62. Yuvaraj, M.; Subramanian, K.S. Different Types of Hydroponics System. Biot. Res. Today 2020, 2, 835-837.

63. Ani, A.; Gopalakirishnan, P. Automated Hydroponic Drip Irrigation Using Big Data. In Proceedings of the 2020 Second International Conference on Inventive Research in Computing Applications (ICIRCA), Coimbatore, India, 15-17 July 2020; pp. 370-375.

64. Maiti, M.; Saha, T. Understanding Hydroponics and Its Scope in India. Available online: https://justagriculture.in/files/ newsletter / 054.\%20Understanding\%20Hydroponics\%20and\%20Its\%20Scope\%20in\%20India.pdf (accessed on 15 October 2021).

65. Sevostianov, I.; Melnyk, O. Elaboration of Improved Hydroponic Installations, Vibrations In Engineering And Technology/VSAU Journals, 29 June 2021. pp. 66-75. Available online: http:/ / socrates.vsau.org/repository/getfile.php/28951.pdf (accessed on 15 October 2021).

66. Schroeder, F.G.; Lozoya, D.R.; Ruser, P. Hydroponic forcing of saffron (Crocus sativus L.). In Proceedings of the XXX International Horticultural Congress IHC2018: II International Symposium on Soilless Culture and VIII International Symposium on Seed, Transplant and Stand Establishment of Horticultural Crops, Istanbul, Turkey, 23 March 2020; pp. 281-288. 
67. Fallahi, H.R.; Abbasi Aval Bohlooli, S.; Pahlavan, Z.; Hosseini, S.M.; Hosseini, S.A.H.; Ghohestani-Bojd, P. Saffron vegetative growth as affected by transplanting and direct corm planting under field conditions. J. Hortic. Postharvest Res. 2021, 4, 1-10.

68. Souret, F.F.; Weathers, P.J. The growth of saffron (Crocus sativus L.) in aeroponics and hydroponics. J. Herbs Spices Med. Plants 2000, 7, 25-35. [CrossRef]

69. Hidayanti, F.; Rahmah, F.; Sahro, A. Mockup as Internet of Things Application for Hydroponics Plant Monitoring System. Int. J. Adv. Sci. Technol. 2020, 29, 5157-5164.

70. Boonnam, N.; Pitakphongmetha, J.; Kajornkasirat, S.; Horanont, T.; Somkiadcharoen, D.; Prapakornpilai, J. Optimal plant growth in smart farm hydroponics system using the integration of wireless sensor networks into internet of things. Adv. Sci. Technol. Eng. Syst. J. 2017, 2, 1006-1012. [CrossRef]

71. Pitakphongmetha, J.; Boonnam, N.; Wongkoon, S.; Horanont, T.; Somkiadcharoen, D.; Prapakornpilai, J. Internet of things for planting in smart farm hydroponics style. In Proceedings of the 2016 International Computer Science and Engineering Conference (ICSEC), Chiang Mai, Thailand, 1-5 December 2016; pp. 1-5.

72. Sutikno, T.; Purnama, H.S.; Pamungkas, A.; Fadlil, A.; Alsofyani, I.M.; Jopri, M.H. Internet of things-based photovoltaics parameter monitoring system using NodeMCU ESP8266. Int. J. Electr. Comput. Eng. 2021, 11, 2088-8708. [CrossRef]

73. Upadhyay, H.; Juneja, S.; Juneja, A.; Dhiman, G.; Kautish, S. Evaluation of Ergonomics-Related Disorders in Online Education Using Fuzzy AHP. Comput. Intell. Neurosci. 2021, 2021, 2214971. [CrossRef] [PubMed]

74. Juneja, A.; Juneja, S.; Soneja, A.; Jain, S. Real time object detection using CNN based single shot detector model. J. Inf. Technol. Manag. 2021, 13, 62-80. [CrossRef]

75. Upadhyay, H.K.; Juneja, S.; Maggu, S.; Dhingra, G.; Juneja, A. Multi-criteria analysis of social isolation barriers amid COVID-19 using fuzzy AHP. World J. Eng. 2021. [CrossRef]

76. Dhankhar, A.; Juneja, S.; Juneja, A.; Bali, V. Kernel parameter tuning to tweak the performance of classifiers for identification of heart diseases. Int. J. E-Health Med. Commun. 2021, 12, 1-16. [CrossRef]

77. Juneja, S.; Gahlan, M.; Dhiman, G.; Kautish, S. Futuristic Cyber-Twin Architecture for 6G Technology to Support Internet of Everything. In Scientific Programming; Hindawi Limited: London, UK, 2021. [CrossRef]

78. Zeidabadi, F.A.; Doumari, S.A.; Dehghani, M.; Montazeri, Z.; Trojovsky, P.; Dhiman, G. MLA: A New Mutated Leader Algorithm for Solving Optimization Problems. CMC-Comput. Mater. Contin. 2022, 70, 5631-5649. [CrossRef]

79. Zeidabadi, F.A.; Doumari, S.A.; Dehghani, M.; Montazeri, Z.; Trojovsky, P.; Dhiman, G. AMBO: All Members-Based Optimizer for Solving Optimization Problems. CMC-Comput. Mater. Contin. 2022, 70, 2905-2921. [CrossRef]

80. Balakrishnan, A.; Ramana, K.; Dhiman, G.; Ashok, G.; Bhaskar, V.; Sharma, A.; Gaba, G.S.; Masud, M.; Al-Amri, J.F. Multimedia Concepts on Object Detection and Recognition with F1 Car Simulation Using Convolutional Layers. Wirel. Commun. Mob. Comput. 2021, 2021, 5543720. [CrossRef]

81. Dhiman, G.; Kaur, G.; Haq, M.A.; Shabaz, M. Requirements for the Optimal Design for the Metasystematic Sustainability of Digital Double-Form Systems. Math. Probl. Eng. 2021, 2021, 2423750. [CrossRef]

82. Kansal, L.; Gaba, G.S.; Sharma, A.; Dhiman, G.; Baz, M.; Masud, M. Performance Analysis of WOFDM-WiMAX Integrating Diverse Wavelets for 5G Applications. Wirel. Commun. Mob. Comput. 2021, 2021, 5835806. [CrossRef]

83. Viriyasitavat, W.; Da Xu, L.; Dhiman, G.; Sapsomboon, A.; Pungpapong, V.; Bi, Z. Service Workflow: State-of-the-Art and Future Trends. IEEE Trans. Serv. Comput. 2021. [CrossRef]

84. Vaishnav, P.K.; Sharma, S.; Sharma, P. Analytical review analysis for screening COVID-19 disease. Int. J. Mod. Res. 2021, 1, 22-29.

85. Chatterjee, I. Artificial intelligence and patentability: Review and discussions. Int. J. Mod. Res. 2021, 1, 15-21.

86. Kumar, R.; Dhiman, G. A comparative study of fuzzy optimization through fuzzy number. Int. J. Mod. Res. 2021, 1, 1-14. 